\title{
Parental Attitudes of Preschool Children toward Students with Special Needs in Inclusive and Non-Inclusive Kindergartens: A Comparative Study
}

\section{Hanifah Sabila ${ }^{a}$ and Farida Kurniawati ${ }^{b}$}

a Faculty of Psychology, Universitas Indonesia, Depok, Indonesia; ${ }^{b}$ Department of Educational Psychology, Faculty of Psychology, Universitas Indonesia, Depok, Indonesia

*Corresponding Author:

Farida Kurniawati

Department of Educational Psychology

Faculty of Psychology, Universitas Indonesia

Jl. Lkr. Kampus Raya, Depok, Jawa Barat

Indonesia, 16424

Tel.: +62 217270004

Email address: farida1@ui.ac.id / fafadana@gmail.com 


\title{
Parental Attitudes of Preschool Children toward Students with Special Needs in Inclusive and Non-Inclusive Kindergartens: A Comparative Study
}

\begin{abstract}
This study investigated the differences between the parental attitudes of regular students toward students with special needs in inclusive and non-inclusive kindergartens. The researchers explored whether variable demographic characteristics such as gender, level of education, and experiences of interacting with disabled people correlated with the attitudes of the parents toward students with special needs in inclusive and non-inclusive kindergartens. The distance of the school from home was also assessed to understand the parents' choice of their children's schools. This study collected questionnaire data from 245 parents (227 mothers and 18 fathers) of regular preschool students attending an inclusive kindergarten and a non-inclusive kindergarten. Parental attitudes were measured using the Parent Attitude toward Children with Handicaps (PATCH) questionnaire, which has 30 items and a Cronbach's alpha coefficient of 0.926. The items in the PATCH are designed to explore parental attitudes toward regular students interacting with special needs students from affective, cognitive, and behavioral dimensions. It was found that there were no differences in parental attitudes toward students with special needs in the inclusive and non-inclusive kindergartens.
\end{abstract}

Keywords: parents, attitude, student with special needs, inclusive preschool.

\section{Introduction}

There are still many children with special needs in Indonesia who find it difficult to attend school because of refusals from the schools, teachers, or the parents of non-special needs students (regular students) (Pendidikan Inklusi Bagi Anak-anak Berkebutuhan Khusus, 2017). The National Socio-Economic Survey conducted by the Indonesian Statistical Center in 2016 found that as many as 4.6 million children were not attending school, 1 million of which were children with special needs (Olyvia, 2017). This was also consistent with the data collected in this study which found that some inclusive kindergartens still only accepted only 1-2 special needs children in one class, which tended to confirm that special needs children in Indonesia still face difficulties in attending school even at the preschool level.

Inclusive education is one of the solutions for students with special needs seeking to attend regular schools. Inclusion is when children with special needs are educated in the regular education classroom of the neighborhood schools they would have attended if they did not have a special need, and are provided with the services and support they need (Rafferty, Boettcher, \& Griffin, 2001). Inclusion therefore provides education access to children with special needs to fulfill their rights to education and allows them to develop along with their peers in general education settings (UNICEF, 2012). The Individuals with Disabilities Education Act (2004) states that an inclusive schools allow students with special needs to be educated with regular children from 3-5 years (Justice, Logan, Lin, \& Kaderavek, 2014). Some research has found that preschool inclusion programs have several benefits for typical children (regular students), such as learning to accept human differences, reducing prejudice and the formation of stereotypes about people who look and behave differently, and raising awareness of the needs 
of other children. Inclusion programs also have benefits for the children with special needs by helping them become members of the larger community, and having role models and peers from whom they can learn adaptive behavior (Bennet, Deluca, \& Bruns, 1997; Buysee \& Bailey, 1993; Rafferty et al., 2001; Stoiber, Gettinger, \& Goetz, 1998).

Stoiber et al. (1998) identified several factors that affected the success of inclusive program implementation such as participation and the attitudes of the teachers, head teachers, peers, and parents (Stoiber et al., 1998), and it has been found that children with special needs were less accepted by their peers because of the negative attitudes of the regular students (De Boer, Pijl, \& Minnaert, 2010). Attitudes, therefore, can have a significant influence on inclusive education as they can influence the process and standards associated with the inclusive education practices for children with special needs (Tafa \& Manolistis, 2003). Further, the attitudes and behavior of parents can heavily influence how their children behave in their daily conversations by the way they answer the child's questions and through the behaviors the parents exhibit when interacting with children with special needs (Innes \& Diamond, 1999). As parental attitudes affect the acceptance of the child to peers with special needs, parental attitudes toward students with special needs can affect the success of inclusive education.

Attitude is a combination of cognitive, affective, and behavioral factors, with the cognitive factor reflecting a person's ideas about an object, the affective factor reflecting their feelings and emotions about an object, and the behavioral factor reflecting their actions toward the object (Triandis, Adamopoulos, \& Brinberg, 1984) after evaluation (Oskamp \& Schultz, 2005). Parental attitudes toward children with special needs in inclusive education have been seen to be influenced by several other factors such as parental gender, parental education level (Stoiber et al., 1998), experience with disabled people (Green \& Stonema, 1989), and experience with various disability types (Tafa \& Manolitsis, 2003).

Previous research has found that parents from both inclusive and non-inclusive schools generally have a positive attitude toward inclusive preschool programs for children with special needs, both for the parents of the students with special needs and for the parents of the regular students (Rafferty et al., 2001; Stoiber et al., 1998; Tafa \& Manolistis, 2003; Green \& Stoneman, 1989), primarily because the parents feel that their children benefit if they are able to interact with special needs children at school. However, Hu and Szente (2010) found that the parents of regular students were against special needs children being educated in the same classroom because they felt that their own children's learning would be disrupted.

However, parents' attitudes toward the benefits of inclusive education influence the parents' decisions as to which schools they prefer for their children. Jenkinson (1998) found that there was a relationship between school selection and parental preferences; that is when parents choose inclusive schools, this indicates their preference for inclusive education.

Therefore, this study sought to determine whether there were any differences in the attitudes of preschool parents toward special needs children who send their children to inclusive and non-inclusive kindergartens through an examination of demographics such a gender, education 
level, experience of interacting with disabled people, and reasons for school selection based on distance and school quality. The hypothesis driving this study was that parents who send their children to inclusive kindergartens have a more positive attitude toward children with special needs than parents who send their children to non-inclusive kindergartens. This research was a baseline study to assess the need for interventions to change the attitude of parents of preschool students toward children with special needs.

\section{Methods}

\section{Respondents and Research Procedures}

The respondents in this study were parents of regular students in inclusive and non-inclusive kindergartens. A total of 516 questionnaires were distributed to six inclusive and seven noninclusive kindergartens in Jakarta and Depok, with 120 from inclusive and 125 from noninclusive kindergartens being returned and used for the data analyses $(92.7 \%$ mothers $(\mathrm{N}=227)$ and $7.3 \%$ fathers $(\mathrm{N}=18)$ ). The 120 returns from the inclusive kindergarten consisted of $95 \%$ mothers $(\mathrm{N}=114)$ and $5 \%$ fathers $(\mathrm{N}=6)$, and the 125 returns from the non-inclusive kindergarten consisted of $90.4 \%$ mothers $(\mathrm{N}=113)$ and $8.8 \%$ fathers $(\mathrm{N}=11)$.

The age range of the parents who participated in this study was 24-52 years with an average age of 34.86 ( $\mathrm{SD}=4.83$ ), the education level varied from elementary to postgraduate level; primary school, $0.4 \%(\mathrm{~N}=1)$, junior high school, 1.22\% $(\mathrm{N}=3)$, senior high school, 26.94\% $(\mathrm{N}=66)$; diploma-1, 0.82\% ( $\mathrm{N}=2)$, diploma-2, 0.4\% ( $\mathrm{N}=1)$, diploma-3, 9.8\% ( $=24)$, undergraduate degree, $50.2 \%(\mathrm{~N}=123)$, and postgraduate degree, $10.2 \%(\mathrm{~N}=25)$.

Accidental sampling was employed based on the parents who were willing to voluntarily complete the research questionnaires. The sample recruitment process involved the submission of request letters to inclusive and non-inclusive kindergartens in Jakarta and Depok and the data were collected from schools that gave permission for the distribution of the questionnaires to the parents of regular students.

\section{Research Instrument}

Data were collected using the Parental Attitude toward Children with Handicaps (PATCH) instrument developed by Rosenbaum, Armstrong, and King (1987), which has 30 Likert type scale items scaled from 1 (strongly disagree) to 4 (strongly agree), all of which explored the attitudes of the parents of regular children to children with special needs across affective, cognitive, and behavioral dimensions. The instrument reliability was found to be 0.917 based on the adaptation results from Aini (2018) in a survey of 310 parents of regular students at an elementary school. A pilot study on the parents of regular students in an inclusive kindergarten also found the reliability of the PATCH measuring instrument to be 0.926 .

\section{Statistical Analysis}

The differences in the parental attitudes toward students with special needs were examined using a non-parametric Mann-Whitney U Test technique because of the abnormal data distribution found in the normality tests. The Kruskal-Wallis Test was also employed to assess 
the differences in the parental attitude scores based on education level and school selection reasons. The differences in parental attitudes based on gender and experience with disabled people were assessed using the Mann-Whitney U Test.

\section{Results}

\section{Differences in Parental Attitudes toward Students with Special Needs}

The Mann-Whitney U Test indicated that there were no significant differences in the parental attitudes toward children with special needs between parents who sent their children to inclusive kindergartens $(\mathrm{Md}=2.88, \mathrm{n}=120)$ and parents who sent their children to non-inclusive kindergartens $(\mathrm{Md}=2.83, \mathrm{n}=125), \mathrm{U}=6491, \mathrm{z}=-1.822, \mathrm{p}=0.068, \mathrm{r}=0.12$.

Table I. Differences in Parental Attitudes toward Students with Special Needs

\begin{tabular}{|l|c|l|c|c|}
\hline & $\mathbf{N}$ & Mean & SD & Sig. \\
\hline Inclusive kindergartens & 120 & 2.96 & 0.28 & \multirow{2}{*}{0.068} \\
\hline Non-inclusive kindergartens & 125 & 2.88 & 0.27 & \\
\hline
\end{tabular}

\section{Gender Differences in Parental Attitudes}

The analysis of the gender variables at the inclusive kindergartens indicated that there was no significant difference toward students with disability $(U=273.5, z=-0.826, p=0.409, r=.05)$ between mothers $(\mathrm{Md}=2.9 \mathrm{n}=114)$ and fathers $(\mathrm{Md}=2.84, \mathrm{n}=6)$, and the gender analysis at the non-inclusive kindergartens also found no differences $(\mathrm{U}=668, \mathrm{z}=-0.084, \mathrm{p}=0.933, \mathrm{r}=$ $0.008)$ between mothers $(\mathrm{Md}=2.83 \mathrm{n}=113)$ and fathers $(\mathrm{Md}=2.88 \mathrm{n}=12)$.

\section{Differences in Parental Attitude Based on Experience Interacting with Disabled People}

A significant difference in parental attitudes toward students with special needs was found between parents who had had some experience with disabled people and parents who had had no experience. In the inclusive kindergartens, the parents who had had disabled person experiences had a higher median score $(\mathrm{Md}=2.9, \mathrm{n}=82)$ than parents who had never had such experiences $(\mathrm{Md}=2.83, \mathrm{n}=38), \mathrm{U}=1133.5, \mathrm{z}=-2.398, \mathrm{p}=0.016, \mathrm{r}=0.242)$, and in the noninclusive kindergartens, there were significant differences found in parental attitude between parents who had had disabled person experiences $(\mathrm{Md}=2.87, \mathrm{n}=87)$ and parents who had not $(\mathrm{Md}=2.82, \mathrm{n}=38) ; \mathrm{U}=1266, \mathrm{z}=-2.081, \mathrm{p}=0.037, \mathrm{r}=0.21$.

\section{Differences in Parental Attitude Based on Education Level}

The Kruskal-Wallis Test revealed no differences in parental attitude across the eight different educational levels in both the inclusive and non-inclusive kindergartens: inclusive kindergarten, $\chi^{2}(7, \mathrm{n}=120)=12.353, \mathrm{p}=0.09$; non-inclusive kindergarten, $\chi^{2}(5, \mathrm{n}=125)=8.793, \mathrm{p}=$ 0.118. The mean score details for each education level are shown in Table 2.

\section{Differences in Parental Attitude Based on School Selection}

The Kruskal-Wallis Test result found no significant differences in parental attitude based on school selection in both the inclusive and non-inclusive kindergarten groups; however, at the inclusive kindergartens, the school selection reasons of good quality and far from home had the 
highest median score $(\mathrm{Md}=3.13, \mathrm{n}=13)$, followed by other reasons $(\mathrm{Md}=3.02, \mathrm{n}=6)$, and school far from home $(\mathrm{Md}=2.98, \mathrm{n}=2), \chi^{2}(4, \mathrm{n}=120)=6.175, \mathrm{p}=0.186$, and in the noninclusive kindergarten, the highest median score was other reasons $(\mathrm{Md}=3.3, \mathrm{n}=3)$, followed by good quality and near to home $(\mathrm{Md}=2.87, \mathrm{n}=90)$, and far from home $(\mathrm{Md}=2.83, \mathrm{n}=1)$, $\chi^{2}(4, \mathrm{n}=125)=7.069, \mathrm{p}=.132$. The detailed mean scores for each level are shown in Table 2 .

Table II. Differences in Parental Attitude toward Students with Special Needs between Inclusive and Non-Inclusive Kindergarten Based on Demographic Variables

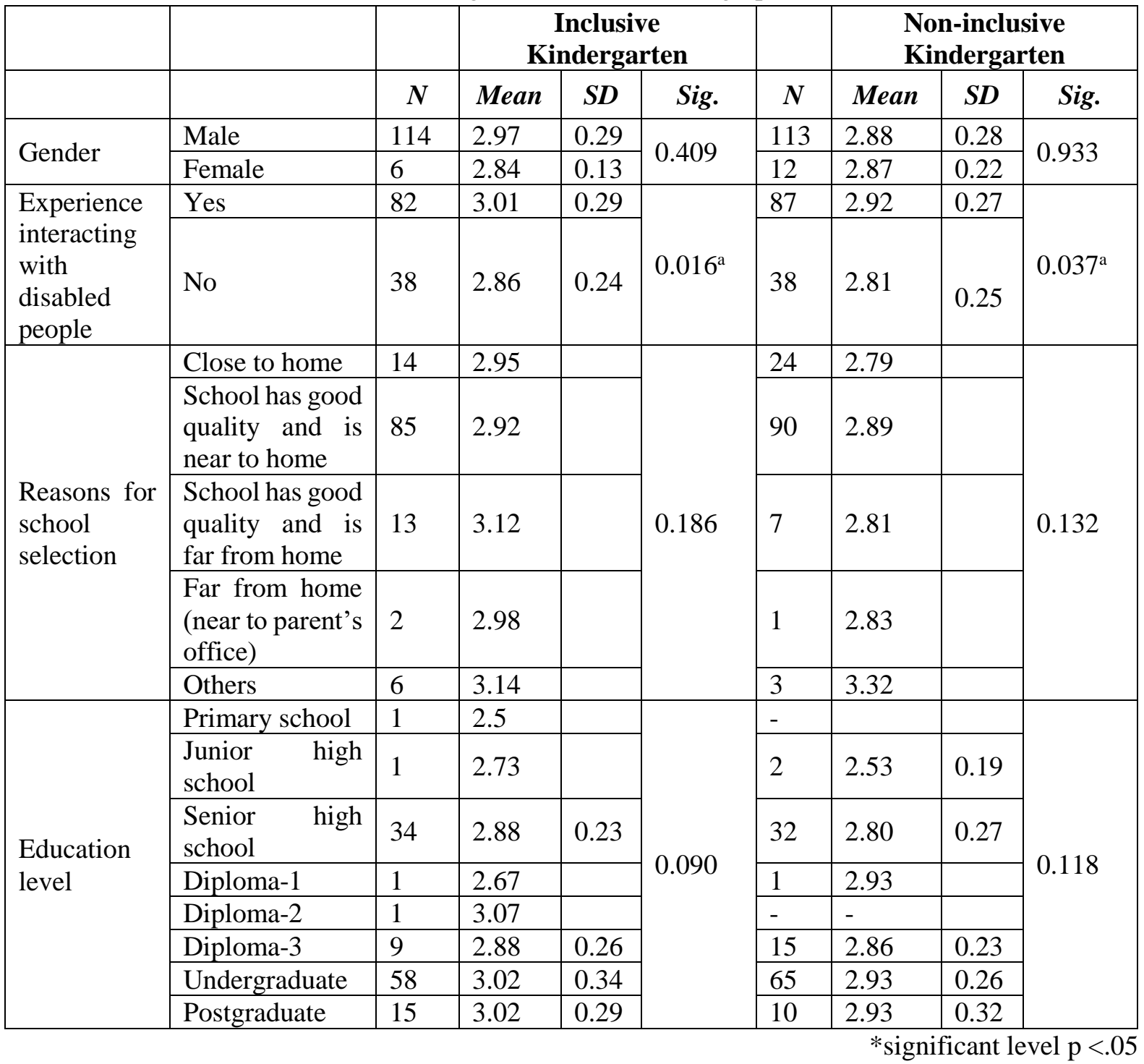

\section{Discussion and Conclusion}

This study examined the differences in the parental attitudes of preschool children toward students with special needs in inclusive and non-inclusive kindergartens, from which it was found that there were no significant differences. Overall, parents from both kindergarten types were found to have a positive attitude toward students with special needs, which was consistent with the results of previous research. The parents agreed that inclusive education had advantages for their children because the children could learn to accept differences. 
The similarities in the parental attitudes was also observed in their school selection reasons, with most parents of both the inclusive and non-inclusive kindergarten children selecting schools that were of good quality and close to their home, which tended to indicate that even though parents may have a positive attitude toward children with special needs, they did not necessarily choose inclusive schools as quality and proximity to home were more important.

The main differences in parental attitude were found between parents who had had experiences with disabled people and parents who had not had such experiences, with the former being found to have higher average attitude scores. This result was consistent with the results in Tafa and Manolistis (2003). Favazza, Ostrosky, and Mouzourou (2015) also confirmed that a key factor in attitude formation is the experience of having direct interactions with people with disabilities.

No significant differences in parental attitudes toward children with special needs were found for education, which was in line with the results in Kalyva, Georgiadi, and Tsakiris (2007) and Tafa and Manolistis (2003). There were also no attitudinal differences found between mothers and fathers toward children with special needs at both the inclusive and non-inclusive kindergartens. Tafa and Manolistis (2003) claimed, however, that positive parental attitudes were more influenced by the mother's attitude as the father's attitude was influenced by the mother's attitude.

The results of this study provide information about the parental attitudes of preschool children's parents toward students with special needs and support the implementation of inclusive education in Indonesia, especially at the preschool level.

However, there were several study limitations. First, we did not explore the parental perceptions of the benefits and risks for regular children attending inclusive programs, the behavioral changes that might occur, and the possible developmental aspects. Second, it was not possible to determine why the parents had a positive attitude. Therefore, further research is needed to more deeply understand the parents' perspectives on the benefits and risks associated with their children's attendance in inclusive programs.

\section{References}

Aini, F. (2018). The effectiveness of SERASI intervention program for improving parents positive attitude towards student with disabilities. (unpublished).

Bennet, T., Deluca, D., \& Bruns, D. (1997). Putting inclusion into practice: perspectives of teachers and parents. Exceptional Children, 64(1), 115-131.

Buysee, V., \& Bailey, D. B. (1993). Behavioral and developmental outcomes in young children with disabilities in integrated and segregated settings: A review of comparative studies. The Journal of Special Education, 26(4), 434-461.

De Boer, A., Pijl, S. J., \& Minnaert, A. (2010). Attitudes of parents towards inclusive education: a review of the literature. European Journal of Special Needs Education, 25(2), 165-181.

Favazza, P. C., Ostrosky, M. M., \& Mouzourou, C. (2015). The making friends program: Supporting acceptance in your K-2 classroom, Brokes Publishing.

Green, A. L., \& Stoneman, Z. (1989). Attitudes of mothers and fathers of nonhandicapped children. Journal of Early Intervention, 13(4), 292-304. 
Hu, B., \& Szente, J. (2010). An introduction to Chinese early childhood inclusion. International Journal of Early Childhood, 42(1), 59-66.

Innes, F. K., \& Diamond, K. E. (1999). Typically developing children's interactions with peers with disabilities: relationships between mothers' comments and children's ideas about disabilities. Topics in Early Childhood Special Education, 19(2), 103-111.

Justice, L. M., Logan, J. A., Lin, T. J., \& Kaderavek, J. N. (2014). Peer effects in early childhood education: Testing the assumptions of special-education inclusion. Psychological Science, 25(9), 1722-1729.

Jenkinson, J. C. (1998). Parent choice of the education of students with disabilities. International Journal of Disability, Development, and Education, 45(2), 189-202.

Kalyva, E., Georgiadi, M., \& Tsakiris, V. (2007). Attitudes of Greek parents of primary school children without special educational needs to inclusion. European Journal of Special Needs Education, 22(3), 295-305.

Olyvia, F. (2017). Satu Juta Anak Berkebutuhan Khusus Tak Bisa Sekolah. Retrieved from CNN Indonesia: https://www.cnnindonesia.com/nasional/20170829083026-20-237997/satu-juta-anak-berkebutuhankhusus-tak-bisa-sekolah.

Oskamp, S., \& Schultz, P. W. (2005). Attitudes and Opinions (3rd ed.). New Jersey: Lawrence Erlbaum Associates, Inc.

Kementerian Pemberdayaan Perempuan dan Perlindungan Anak. (2017). Pendidikan Inklusi Bagi Anak-anak Berkebutuhan Khusus. Retrieved from Kementrian Pemberdayaan Perempuan dan Perlindungan Anak: https://www.kemenpppa.go.id/index.php/page/read/29/1310/pendidikan-inklusi-bagi-anak-anak-.

Rafferty, Y., Boettcher, Y. C., \& Griffin, K. W. (2001). Benefits and risks of reverse inclusion for preschoolers with and without disabilities: Parents' perspective. Journal of Early Intervention, 14(4), 266-286.

Rosenbaum, P. L., Armstrong, R. W., \& King, S. M. (1987). Parental attitudes toward children with handicaps: new perspective with new measures. Developmental and Behavioral Pediatrics, 8(6), 327-334.

Stoiber, K. C., Gettinger, M., \& Goetz, D. (1998). Exploring factors influencing parents' and early childhood practitioners' beliefs about inclusion. Early Childhood Research Quarterly, 13(1), 107-124.

Tafa, E., \& Manolitsis, G. (2003). Attitudes of Greek parents of typically developing kindergarten children towards inclusive education. European Journal of Special Needs Education, 18(2), 155-171.

Triandis, H. C., \& Adamopoulos, J. \& Brinberg, D. (1984). Perspectives and issues in the study of attitudes. In R. L. Jones (Ed.), Attitudes and Attitude Change in Special Education: Theory and Practice. Virginia: The Council for Exceptional Children.

UNICEF. (2012). The Right of Children with Disabilities to Education. Geneva: UNICEF Regional Office for Central and Eastern Europe and Commonwealth of Independent States (CEECIS). 